\title{
PHOTO CREDITS
}

I would like to thank the following institutions for permission to publish the illustrations reproduced in this book: Archivio di Stato, Bologna (Museum Plan 5); Biblioteca Universitaria, Bologna (figs. 1, 2, 4, 7, 8, 10, 14-16, and 20); Biblioteca Ambrosiana, Milan (Museum Plan 2); Pinacoteca Ambrosiana, Milan (fig. 6); Museo Civico di Storia Naturale, Milan (fig. 26); Museo e Gallerie Nazionali di Capodimonte, Naples (fig. 23); Ugo Guanda Editore, Parma (fig. 21); Bayerische Staatsgemäldesammlungen, Alte Pinakotek, Munich (fig. 3); The British Library, London (figs. 9, 11, and 19); The Bancroft Library, University of California, Berkeley (figs. 17, 18, 24, and 28-30); Department of Special Collections, University of California Library, Davis (figs. 12 and 13); Department of Special Collections, The University of Chicago Library (fig. 5); Rare Books, University of Illinois, Urbana (fig. 27); and Department of Special Collections, Memorial Library, University of Wisconsin-Madison (figs. 22 and 25). 


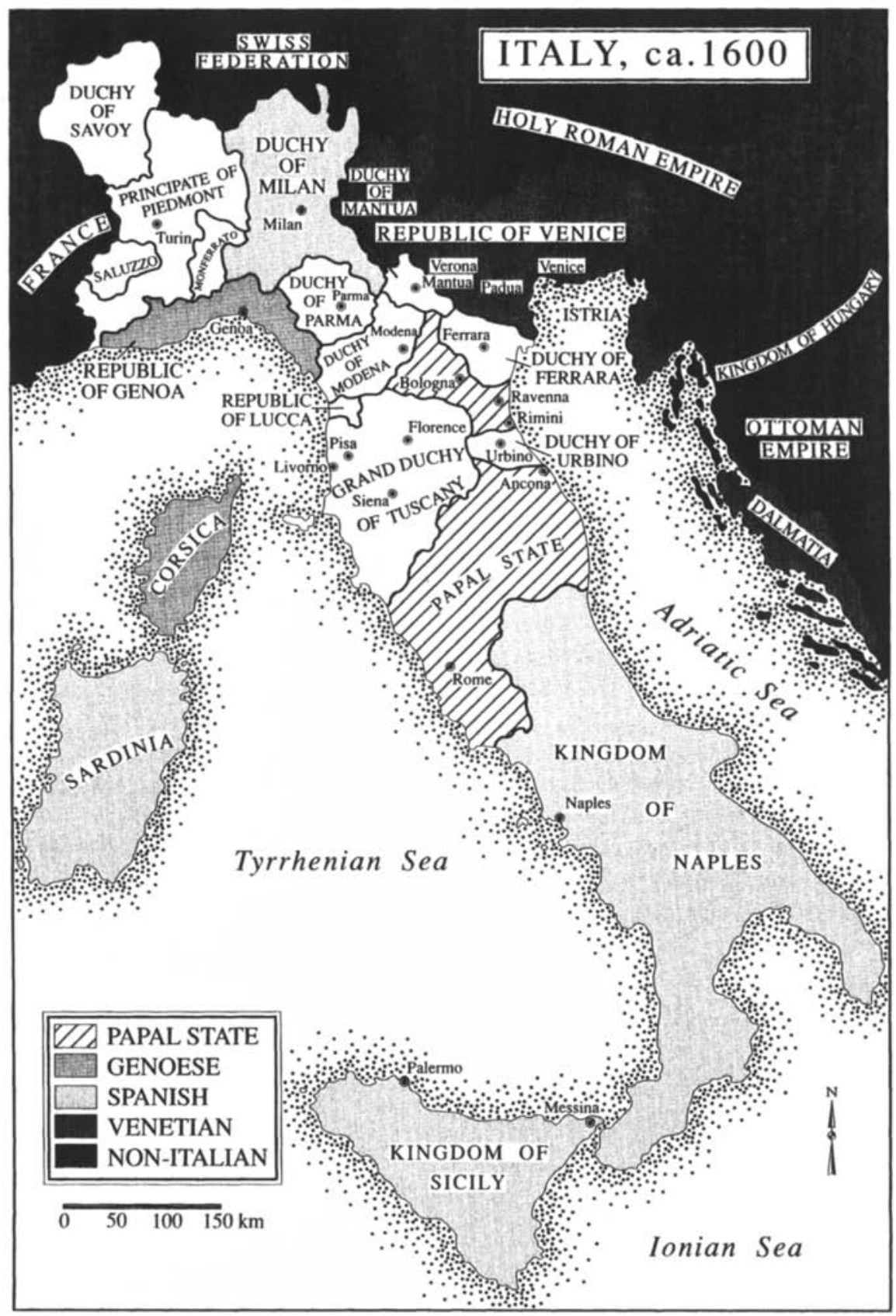

